\title{
Changes and directions of craniofacial surgery in Korea
}

\author{
Yong-Ha Kim \\ Department of Plastic and Reconstructive Surgery, Yeungnam University College of Medicine, Daegu, Korea
}

Craniofacial surgery is at the heart of modern plastic surgery; therefore, the history of craniofacial surgery of Korea has moved hand-in-hand with that of plastic surgery. A breakthrough development in plastic surgery in Korea was the founding of the Korean Society for Plastic Surgery (KSPS) in 1966. With subsequent economic developments, the rapid dissemination of expertise, and major advances in knowledge, the KSPS has developed rapidly, and plastic surgery in Korea is now such an active field that Korea is known as "the capital of plastic surgery," an indicator of Korea's worldwide influence in this domain [1,2]. As Korean society has become more highly developed and structurally complex, specialized professional meetings have become necessary among plastic surgeons. In the early years of the field, specialists in craniofacial surgery gathered to satisfy their academic thirst at conference meetings, where papers were read and patients were discussed. In 1993, the Korean Association for Cleft Palate and Related Craniofacial Anomalies was founded, with professor Park Byung-yoon as the first chairman. Since then, the society has evolved; notably, it has been renamed the Korean Cleft Palate-Craniofacial Association (KCPCA), and it now has its own journal, Archives of Craniofacial Surgery (ACFS) [3].

The domains covered by the KCPCA have also been extended to include areas ranging from congenital malformations, including early cleft lip and palate, to facial fractures and soft tissue trauma, the reconstruction of head and neck tumors, facial

\section{Correspondence: Yong-Ha Kim}

Department of Plastic and Reconstructive Surgery, Yeungnam University College

of Medicine, 170 Hyeonchung-ro, Nam-gu, Daegu 42415, Korea

E-mail: yhkim@med.yu.ac.kr

Received October 13, 2019 / Revised October 14, 2019 / Accepted October 15, 2019 contour surgery including double jaw surgery, and many other facial cosmetic surgical procedures.

\section{Changes}

Changes and advances in society are accompanied by changes in the epidemiological distribution of diseases and treatment strategies. In the past, congenital malformations, including cleft lip and palate, were very common in Korea. During the Korean War, when Korea emerged onto the international stage, Korea was an undeveloped country in which cleft lip and noma were very common. Dr. Millard developed the rotation advancement method when serving as a plastic surgeon at a US Marine camp immediately after the Korean War and performing numerous cleft lip and palate operations [4]. His method has become the most widely used surgical technique for this condition worldwide. Since then, many Korean plastic surgeons have performed surgery on cleft lip and palate patients to normalize their facial structures. Every year, dozens of doctors travel to underdeveloped areas such as Southeast Asia, Central Asia, Africa, and South America to perform cleft lip and palate surgery as a free medical service, indirectly repaying the help we have received, and practicing compassion and humanity.

In the field of facial trauma, severe facial fractures caused by traffic accidents are very frequent. In Korea, plastic surgeons are primarily responsible for the treatment of facial fracture patients. In Europe and the United States, oromaxillofacial surgeons, maxillofacial surgeons, and otolaryngologists play an active role in treating these conditions, but in Korea, plastic surgeons treat almost all facial fractures, including mandibular and orbital fractures. A reason for this is that there are relatively 
many plastic surgeons and relatively few dental schools in Korea. Korean plastic surgeons have obtained extensive experience in the field of facial trauma and have become global leaders in the field of craniofacial surgery. They have contributed to academic development by publishing many papers, performing delicate surgical procedures, and striving to obtain aesthetically favorable long-term results.

In Korea, cosmetic surgery is common among the general public as a way to enhance beauty. This is due both to the openmindedness of Korean society and to the influence of entertainers. Many Korean wave celebrities have undergone facial contour surgery to make themselves look more beautiful. Many celebrities confidently perform, appear in public, and act without hiding that they have undergone surgery. In addition to Koreans, many patients from Southeast Asia, China, and the Middle East visit Korea for facial contour surgery and other cosmetic procedures. It is also common for Korean plastic surgeons to move to Southeast Asia and China. Frequently performed facial contour procedures in Korea include double jaw surgery, malar reduction surgery, mandibular angle ostectomy and contouring surgery, and anterior segmental osteotomy for the correction of protruding mouth. Although these changes have been partially driven by commercial demands, it is clear that they have contributed greatly to the popularization of surgery and to academic progress.

In addition, Korean microvascular surgeons have presented excellent studies evaluating the functional and cosmetic results of reconstruction of head and neck tumors. In other areas, it is well known that rhinoplasty surgery, blepharoplasty surgery, facelifts, and other cosmetic surgical procedures are producing amazing results as a result of surgeons' extensive experience and competition.

We have taken an active approach to coping with changes in the field of diseases and surgical procedures in modern society, and should continue to do so in the future [5].

\section{Dubito ergo cogito}

"Cogito ergo sum (I think, therefore I am)" is the second, not the first, of the postulates in Descartes' philosophy. The first step is "Dubito ergo cogito (I doubt, therefore I think)." Descartes' philosophy is, above all, a reasoned reflection on the experience of what has previously caused doubt. To have doubts is a sure sign that the doubter thinks, and if there is a thought, it must exist [6,7].

Despite the short history of the field, the reasons why plastic surgery in Korea has developed so rapidly, to the point that Korea is a global leader in this field, are as follows: personal effort, a good training system, an open-minded society, lower cosmet- ic surgery costs, and, above all, fierce competition. Only a skilled doctor can succeed and survive, and one will fall behind if one lacks skills. Only by doubting, thinking, learning, reinforcing one's skills, engaging in trial and error, and overcoming problems will one become knowledgeable and overcome the competition.

\section{Direction of the KCPCA}

As president of the KCPCA, I will uphold its traditional values and work closely with related societies and organizations. The KCPCA will continue to strive for members to be recognized externally for their status and rights in their specialty and to maintain their own high standards. Conflict with nonspecialists and other departments is a constant challenge. The KCPCA is dedicated to contributing to the academic development of its field and to enhancing members' competency through various training programs. The KCPCA will provide fora for communications, such as conferences and workshops, and a space for publishing papers (ACFS), enabling members to continue asking questions and engaging in discussions. The KCPCA is committed to helping members share their journey along the path of academic development and to foster and maintain friendships by sharing their knowledge, experiences, and thoughts.

\section{NOTES}

\section{Conflict of interest}

YHK has served as a President of Korean Cleft Palate-Craniofacial Association and editor-in-chief of the Archives of Plastic Surgery, but has no role in the decision to publish this article.

\section{ORCID}

Yong-Ha Kim https://orcid.org/0000-0002-1804-9086

\section{REFERENCES}

1. Kim YB. The history and future of plastic and reconstructive surgery. Arch Plast Surg 2015;42:515-6.

2. Swanson A. Stunning photos show why S. Korea is the plastic surgery capital of the world [Internet]. Washington, DC: The Washington Post; c2015 [cited 2015 May 16]. Available from: https://www.washingtonpost.com/news/wonk/wp/2015/05/16/ stunning-photos-show-why-south-korea-is-the-plastic-surgery-capital-of-the-world/?utm_term=.1406266fe6d9.

3. Kim KS. Korean Cleft Palate-Craniofacial Association: history and perspectives. Arch Craniofac Surg 2019;20:1-2.

4. Millard DR. Cleft craft. Boston: Little Brown; 1976.

5. Kim YH. Why are some periods and places so astonishingly 
more productive than others? Arch Plast Surg 2016;43:391-2.

6. Robelli C. The order of time. London: Penguin Books; 2019.
7. Kim YH. Thinking about Descartes' rules when writing a paper. Arch Plast Surg 2018;45:393-4. 